\title{
Early zygotes are suitable recipients for bovine somatic nuclear transfer and result in cloned offspring
}

\author{
Anita Schurmann, David N Wells and Björn Oback \\ AgResearch Ltd, Ruakura Research Centre, Reproductive Technologies, East Street, Private Bag 3123 Hamilton, New \\ Zealand \\ Correspondence should be addressed to B Oback; Email: bjorn.oback@agresearch.co.nz
}

\begin{abstract}
Cloning by somatic cell nuclear transfer (SCNT) subverts sperm-mediated fertilization that normally leads to physiological activation of the oocyte. Therefore, artificial activation is required and it is presently unclear what developmental consequences this has. In this study, we aimed to improve cattle cloning efficiency by utilizing a more physiological method of activating SCNT reconstructs. We carried out in vitro fertilization (IVF) of zona-intact bovine oocytes before SCNT. We removed the zona pellucida $4 \mathrm{~h}$ after insemination, stained the fertilized eggs with Hoechst 33342 and mechanically removed both male and female chromatin. The enucleated pre-activated cytoplasts were fused with male adult ear skin fibroblasts ('IVF-NT' group). Chemically activated SCNT embryos, produced according to our standard operating procedure for zona-free SCNT, served as controls. After 7 days, in vitro development to blastocysts of morphological grade 1-3 or grade 1-2 was very similar in both groups (39 vs $40 \%$ and 20 vs $21 \%$ respectively). However, post-implantation development was improved after sperm-mediated activation. Across four replicate runs, pregnancy establishment at day 35 was significantly higher for IVF-NT than for control SCNT embryos $(30 / 49=61$ vs $17 / 41=42 \%$ respectively; $P<0.05)$. Development into calves at term or weaning was also higher in the IVF-NT group compared with control SCNT $(9 / 49=18$ vs $3 / 41=7 \%$ and $6 / 49=12$ vs $3 / 41=7 \% ; P=0.11$ and 0.34 respectively).

Reproduction (2006) 132 839-848
\end{abstract}

\section{Introduction}

Hundreds of apparently normal calves have been cloned worldwide after somatic cell nuclear transfer (SCNT) with bovine donor cells. However, these surviving animals represent less than $5 \%$ of all cloned embryos transferred into recipient cows (Oback \& Wells 2003). Most of the remaining 95\% died at various stages of development due to developmental abnormalities, collectively referred to as the 'cloning syndrome'. The cloning syndrome manifests itself at different levels. At the organismal level, typical symptoms encompass placental problems (e.g., placentome malformation and hydroallantois), prolonged gestation, parturition difficulties (e.g., higher placental and birth weights, higher peri- and post-natal death due to dystocia, and respiratory distress), specific adult phenotypes (e.g., musculoskeletal problems and obesity), and shorter life-span (Wells et al. 2004). At the cellular level, cloned pre-implantation embryos suffer from morphological and physiological abnormalities, such as aberrant allocations of inner cell mass (ICM; Koo et al. 2002), higher incidence of apoptosis (Park et al. 2004), and altered metabolic requirements (Chung et al. 2002). At the subcellular level, molecular defects have been described including aberrant methylation patterns of DNA (Bourc'his et al. 2001, Dean et al. 2001, Kang et al. 2001, 2002) and histones (Santos et al. 2003), and dysregulation of imprinted and non-imprinted genes (Humpherys et al. 2002, Mann et al. 2003, Suemizu et al. 2003). At least some symptoms of the cloned phenotype are not transmitted from parent to offspring (Shimozawa et al. 2002, Wells 2003), indicating that the cloned phenotype does not entail changes in DNA sequence and is therefore largely epigenetic. It is believed to be mainly caused by existing epigenetic errors in the donor genome and/or faulty or incomplete reprogramming of epigenetic marks (e.g., modifications of DNA and DNA-binding proteins) imposed on the donor genome during differentiation.

A number of approaches have been devised to increase the frequency of success in epigenetic reprogramming and alleviate the somatic cloning syndrome. These include identifying a better donor cell type or cell cycle stage (Wells et al. 2003), treating donor cells with pharmacological agents to alter their epigenetic marks (Enright et al. 2003, Kishigami et al. 2006), fusing 
transiently permeabilized cells containing artificially condensed chromatin (Sullivan et al. 2004), using serial NT (Ono et al. 2001a, 2001b), or aggregating SCNT embryos (Boiani et al. 2003). Here, we have focused on improving another step of the cloning procedure, namely, the method of SCNT reconstruct activation.

Cloning subverts fertilization, which normally leads to physiological activation of the oocyte. Since NT of somatic donor cells does not activate the recipient oocyte (Czolowska et al. 1984, Szollosi et al. 1986, 1988), artificial activation protocols have been employed to mimic sperm-induced activation events (Graham 1974, Tarkowski 1975, Wittingham 1980, Kaufman 1983, Yanagimachi 1994). These events include triggering of the inositol-1,4,5-trisphosphate signal transduction cascade that leads to transient intracellular calcium oscillations, initiation of the cortical granule reaction, degradation of cyclin B and Cdk 1 (formerly p34 ${ }^{\text {cdc2 }}$ ) complexes (M-Cdk, formerly maturation promoting factor or MPF), and formation of the diploid zygote. Procedures were developed to activate young mammalian oocytes by completely and continuously suppressing the activity of M-Cdk (Liu \& Yang 1999). In a variety of species, most SCNT activation protocols work by either administering a single artificial stimulus, e.g., electric current (Wilmut et al. 1997, Baguisi et al. 1999) or strontium (Wakayama et al. 1998), or sequentially applying two consecutive stimuli, e.g., electric current or calcium ionophore followed by chemicals known to suppress $\mathrm{M}$-Cdk re-formation or activity, such as blockers of translation (Kato et al. 1998) or broad-spectrum protein kinase-inhibitors (Susko-Parrish et al. 1994) respectively. Comparative studies have not found any significant differences in cloning efficiency between different artificial oocyte-activating agents (Kishikawa et al. 1999, Galli et al. 2002). However, the origin, frequency, and amplitude of calcium oscillations are altered in artificially activated eggs (Deguchi et al. 2000). An electric pulse (Sun et al. 1992), ethanol (Cuthbertson et al. 1981), or calcium ionophore (Colonna et al. 1989) typically induce a single, large calcium rise instead of the long-lasting repeated calcium oscillations, which are caused by sperm (Miyazaki et al. 1986) or sperm factors (Swann \& Ozil 1994). While this is sufficient to trigger cortical granule exocytosis and resumption of meiosis, it does not, for example, down-regulate the inositol-1,4,5trisphosphate receptor (Brind et al. 2000, Jellerette et al. 2000). Furthermore, paternal mRNAs and proteins are delivered to the oocyte during fertilization and may be beneficial for early embryonic development (Ostermeier et al. 2004). In summary, artificial activation and fertilization are functionally non-equivalent and one might expect different developmental consequences as a result of different activation protocols.

In this study, we aimed to improve cattle cloning efficiency by utilizing a more physiological method of artificially activating SCNT reconstructs. In order to achieve this, we in vitro fertilized bovine oocytes for $4 \mathrm{~h}$ and enucleated them at the telophase II (TII)-stage, just before NT with adult ear skin fibroblasts (AESF-1). Artificially activated SCNT embryos produced according to our standard operating procedure (SOP) for zona-free SCNT (Oback \& Wells 2003) served as controls.

\section{Materials and Methods}

Chemicals were supplied by Sigma and all embryo manipulations were carried out at $38.5^{\circ} \mathrm{C}$ unless indicated otherwise. All NT experiments were direct contemporaneous comparisons, that is, within each NT experiment, all parameters other than the activation method (spermmediated versus chemical), were kept the same (e.g. donor cells, pool of oocytes, culture medium, and recipient population for embryo transfer). Investigations were conducted in accordance with the regulations of the New Zealand Animal Welfare Act 1999.

\section{Nuclear donor cells}

A primary male AESF-1 cell line (passage 4-6) was used for NT. Fibroblasts were isolated and cultured as described in detail previously (Oback \& Wells 2003). Prior to NT, cells were seeded at $2.5 \times 10^{4} / \mathrm{cm}^{2}$. After 17-20 h, they were washed thrice with PBS and cultured in medium containing $0.5 \%(\mathrm{v} / \mathrm{v})$ fetal calf serum (FCS) for 6 days (Campbell et al. 1996).

\section{In vitro maturation of oocytes (IVM)}

In vitro matured non-activated metaphase II (MII)arrested oocytes were derived as described previously (Oback \& Wells 2003). Briefly, slaughterhouse ovaries were collected from mature cows, placed in saline $\left(30^{\circ} \mathrm{C}\right)$, and transported to the laboratory within $2-4 \mathrm{~h}$. Cumulus-oocyte complexes (COCs) were collected in Hepes-buffered medium 199 (H199) (Life Technologies; Cat.-no. 31100-035) containing $15 \mathrm{mM}$ Hepes, $5 \mathrm{mM}$ $\mathrm{NaHCO}_{3}, 0.086 \mathrm{mM}$ kanamycin monosulfate, with $925 \mathrm{IU} \mathrm{ml}^{-1}$ heparin (Artex Ltd, Waipukurau, New Zealand), and $20 \mu \mathrm{l} / \mathrm{ml} 20 \%$ (w/v) albumin concentrate (Immuno-Chemical Products Tbio (ICP bio), Auckland, New Zealand) by aspirating 3-12 mm follicles into a $15 \mathrm{ml}$ tube using an 18-gauge needle and negative pressure $(40-50 \mathrm{mmHg})$. Only COCs with a compact, non-atretic cumulus oophorus-corona radiata, and a homogenous ooplasm were selected for IVM. COCs were washed twice in $\mathrm{H} 199$ with $10 \%$ (v/v) FCS (H19910) and once in bicarbonate-buffered medium M199 with $25 \mathrm{mM} \mathrm{NaHCO}$, $0.2 \mathrm{mM}$ pyruvate, $0.086 \mathrm{mM}$ kanamycin monosulfate, and 10\% (v/v) FCS (B199-10). Ten COCs in $10 \mu \mathrm{l}$ of B199-10 were transferred into a $40 \mu \mathrm{l}$ drop of IVM medium comprising B199-10 with $10 \mu \mathrm{g} / \mathrm{ml}$ ovine 
follicle-stimulating hormone (Ovagen; ICPbio), $1 \mu \mathrm{g} / \mathrm{ml}$ ovine luteinizing hormone (ICPbio), $1 \mu \mathrm{g} / \mathrm{ml} 17-\beta-$ estradiol, and $0.1 \mathrm{mM}$ cysteamine in $6 \mathrm{~cm}$ dishes (Falcon 35-1007, Becton Dickinson Labware, Lincoln Park, NJ, USA) overlaid with paraffin oil (Squibb, Princeton, NJ, USA).

\section{In vitro fertilization (IVF)}

In vitro-matured oocytes were fertilized at 20-22 h poststart of maturation as described previously (Thompson etal. 2000). Briefly, spermatozoa were prepared from frozenthawed semen obtained from a sire that had been characterized as suitable for IVF in the laboratory. The contents of one $0.25 \mathrm{ml}$ straw (containing approximately $1 \times 10^{8}$ spermatozoa $/ \mathrm{ml}$ ) was layered upon a Percoll gradient (45:90\%), and motile spermatozoa were collected after centrifugation at approximately $700 \boldsymbol{g}$ for $20 \mathrm{~min}$ at room temperature. The motile fraction was washed once in $1 \mathrm{ml}$ Hepes-buffered synthetic oviduct fluid (HSOF; $107.7 \mathrm{mM} \mathrm{NaCl}, 7.15 \mathrm{mM} \mathrm{KCl}, 0.3 \mathrm{mM} \mathrm{KH}_{2} \mathrm{PO}_{4}, 5 \mathrm{mM}$ NaHCO3, $3.32 \mathrm{mM}$ sodium lactate, $0.069 \mathrm{mM}$ kanamycin monosulfate, $20 \mathrm{mM}$ Hepes, $0.33 \mathrm{mM}$ pyruvate, $1.71 \mathrm{mM} \mathrm{CaCl} 2 \cdot 2 \mathrm{H}_{2} \mathrm{O}$, and $3 \mathrm{mg} / \mathrm{ml}$ fatty-acid free bovine albumin (ABIVP, ICPbio)). Sperm concentration was adjusted to $1 \times 10^{6} \mathrm{sperm} / \mathrm{ml}$ and insemination performed in $50 \mu$ IVF SOF medium $(107.7 \mathrm{mM} \mathrm{NaCl}, 7.15 \mathrm{mM} \mathrm{KCl}$, $0.3 \mathrm{mM} \mathrm{KH} \mathrm{KO}_{4}, 25 \mathrm{mM} \mathrm{NaHCO} 3,3.32 \mathrm{mM}$ sodium lactate, $0.04 \mathrm{mM}$ kanamycin monosulfate, $0.33 \mathrm{mM}$ pyruvate, $1.71 \mathrm{mM} \mathrm{CaCl} 2.2 \mathrm{H}_{2} \mathrm{O}, 8 \mathrm{mg} / \mathrm{ml}$ fatty-acid free bovine albumin (ABIVP, ICPbio), supplemented with $0.001 \mathrm{mM}$ heparin, $0.2 \mathrm{mM}$ penicillamine, and $0.1 \mathrm{mM}$ hypotaurine) under oil (approximately five oocytes per drop) in a humidified modular incubation chamber (ICN Biomedicals Inc., Aurora, $\mathrm{OH}, \mathrm{USA}$ ) gassed with $5 \% \mathrm{CO}_{2}$, $7 \% \mathrm{O}_{2}$, and $88 \% \mathrm{~N}_{2}$.

In pilot experiments, the eggs were fixed in $4 \%$ paraformaldehyde in PBS, stained with $5 \mu \mathrm{g} / \mathrm{ml}$ Hoechst 33342, and scored for disappearance of the MII plate and second polar body extrusion at various times after insemination. In another set of pilot experiments, the proportion of cloned embryos that developed into blastocysts was quantified as a function of the time interval between insemination and NT. Both sets of initial experiments established that an interval of $4-5 \mathrm{~h}$ post-insemination (hpi) was optimal for achieving both high fertilization and development rates. To keep the timing between insemination and NT constant, oocytes were in vitro fertilized in three consecutive batches, $60 \mathrm{~min}$ apart, on each experimental day.

\section{NT and artificial activation}

For each IVF-batch, the cumulus-corona was dispersed $220 \mathrm{~min}$ post-insemination (mpi; equals $23.7-25.7 \mathrm{~h}$ post-IVM) by vortexing in $1 \mathrm{mg} / \mathrm{ml}$ bovine testicular hyaluronidase (Sigma) in HSOF, followed by three washes in HSOF. The zona pellucida was removed with pronase $(5 \mathrm{mg} / \mathrm{ml}$ in $\mathrm{H} 199)$, the presumptive zygotes washed twice in HSOF and placed into drops of Hepes-buffered AgResearch (AgR)-SOF (Wells et al. 2003). Early zygotes were selected for second polar body extrusion at $230 \mathrm{mpi}$, then stained for $5 \mathrm{~min}$ in droplets of $5 \mu \mathrm{g} / \mathrm{ml}$ Hoechst 33342 in $\mathrm{H} 199$ with $1 \mathrm{mg} / \mathrm{ml}$ polyvinyl acetate (PVA, Mr: 10-30000) (H199-PVA) under oil. At $240 \mathrm{mpi}$, enucleation commenced whereby each zygote was constantly exposed to u.v.-light during removal of maternal and paternal chromatin at $100 \times$ total magnification. Bovine zona-free NT was performed using our previously described SOP (Oback \& Wells 2003). Briefly, individual serum-starved cells (selected for relatively small size within the population) were attached to cytoplasts in drops of $10 \mu \mathrm{g} / \mathrm{ml}$ phytohemagglutinin in H199-PVA. At 270-330 mpi (this equals about 25-27 h post-IVM), couplets were electrically fused with $2 \times 10 \mu$ s rectangular DC-field pulses $(2.0 \mathrm{kV} / \mathrm{cm})$ in hypoosmolar fusion buffer $(165 \mathrm{mM}$ mannitol, $50 \mu \mathrm{M}$ $\mathrm{CaCl}_{2}, 100 \mu \mathrm{M} \mathrm{MgCl} 2,500 \mu \mathrm{M}$ Hepes, $0.05 \%(\mathrm{w} / \mathrm{v})$ bovine albumin (ABIVP, ICPbio), pH 7.3) using a custommade parallel-plate fusion chamber connected to an ECM 200 (BTX, San Diego, CA, USA) at room temperature (Gaynor et al. 2005). Successfully fused SCNT reconstructs were placed in in vitro culture drops of AgR-SOF (Wells et al. 2003). An overview of the IVF-NT procedure is illustrated in Fig. 1.

Standard control SCNT embryos were generated according to the same SOP. After IVM for $20.5 \mathrm{~h}$, the

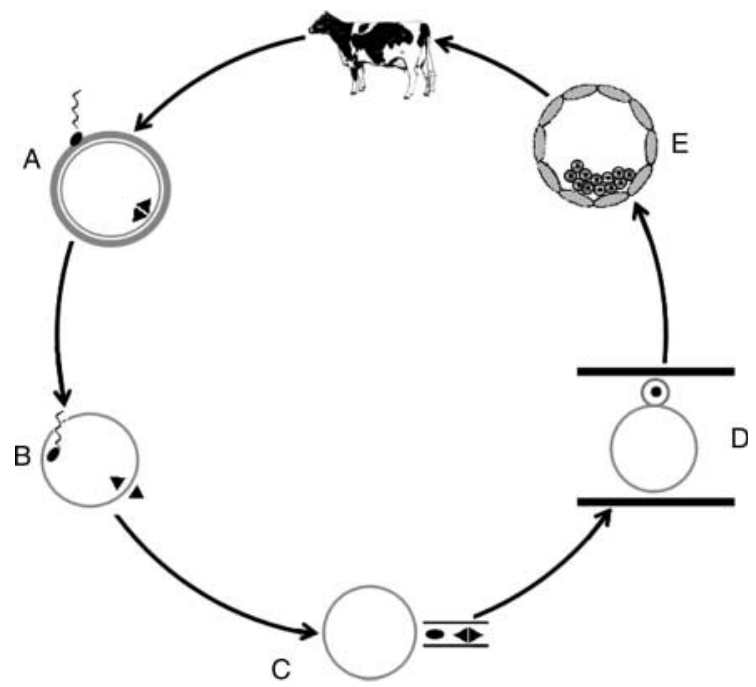

Figure 1 Sperm-mediated activation of NT reconstructs. The IVF-NT cloning procedure comprises five main steps. (A) MII oocytes are fertilized in vitro. (B) Fertilization activates the oocyte. The zona pellucida is removed. (C) Both the decondensing sperm chromatin and the maternal telophase II spindle complex are aspirated, to produce cytoplasts. (D) Lectin-mediated attachment of donor cell to cytoplast and electrical cell fusion of donor-cytoplast couplet. (E) Single in vitro culture of NT reconstruct to blastocyst. 
cumulus-corona was dispersed as described above. After three washes in H199-PVA, the zona pellucida of oocytes with a first polar body was removed by pronase and the eggs held in H199-PVA, until start of enucleation at $21 \mathrm{~h}$ post-IVM. At about $22-23 \mathrm{~h}$ post-IVM, oocyte-donor couplets were electrically fused and reconstructed SCNT embryos were artificially activated 5-6 h post-fusion (range 310-365 min, average $=343 \mathrm{~min}$ post-fusion; this equals $28 \mathrm{~h}$ post-IVM), using a combination of $5 \mu \mathrm{M}$ ionomycin for 4 min and $2 \mathrm{mM}$ 6-dimethylaminopurine (6-DMAP) in AgR-SOF medium with $10 \%(\mathrm{v} / \mathrm{v})$ FCS (Wells et al. 2003). After $4 \mathrm{~h}$ in 6-DMAP (Susko-Parrish et al. 1994), reconstructs were washed thrice in HSOF and transferred into AgR-SOF culture medium droplets. Another set of control experiments utilized NT into artificially preactivated cytoplasts or MII oocytes. Following ionomycin treatment for $4 \mathrm{~min}, 2 \mathrm{mM}$ 6-DMAP was included in all media used for the production NT reconstructs except for the few minutes in fusion buffer during electrofusion. After a total of $4 \mathrm{~h}$ in media containing 6-DMAP, reconstructs were washed thrice in HSOF and transferred into AgR-SOF culture medium droplets.

\section{In vitro culture (IVC)}

Reconstructed embryos were cultured singularly in vitro for 7 days (day $0, \mathrm{D} 0=$ fusion) in $5 \mu \mathrm{l}$ biphasic-AgR-SOF medium (Wells et al. 2003). On D4, embryos were changed into fresh AgR-SOF drops containing $10 \mu \mathrm{M} 2$, 4-dinitrophenol (Thompson et al. 2000) to act as an uncoupler of oxidative phosphorylation. All cultures were overlaid with mineral oil and done in a humidified modular incubation chamber gassed with $5 \% \mathrm{CO}_{2}, 7 \%$ $\mathrm{O}_{2}$, and $88 \% \mathrm{~N}_{2}$.

\section{Embryo transfer, pregnancy monitoring, and controlled calving}

Total embryo development into blastocysts was assessed after 7 days. Morphological grade 1 and 2 blastocysts, that is, those with symmetrical and spherical ICM cells of uniform size, color and density (Robertson \& Nelson 1998) were selected for embryo transfer (ET), even though it has not yet been established that such grading criteria are at all meaningful for cloned embryos or zonafree embryos in particular. Recipient cows were synchronized as described (Oback \& Wells 2003). On D7 following estrus (estrus = D0 = day of NT), a single cloned blastocyst in Emcare embryo holding solution (ICPbio) was loaded per $0.25 \mathrm{ml}$ straw (Cryo-Vet, Quebriac, France) and transferred non-surgically into the uterine lumen ipsilateral to the corpus luteum. Friesian and Hereford $\times$ Friesian cows were used as recipients and embryos from each treatment were randomly allocated to each breed in roughly equal numbers. Using ultrasonography (Aloka SSD-500 scanner with a $5 \mathrm{MHz}$ linear rectal probe, Aloka Co Ltd, Tokyo, Japan) the pregnancy status of recipient cows was determined on D35 of gestation. Development throughout gestation was monitored approximately every 30 days, from D35 to D90 by ultrasonography and thereafter by palpation per rectum. Following a regime to control parturition as described (Oback \& Wells 2003), cows were allowed to calve naturally if at all possible or with manual assistance varying degrees as necessary. On rare occasions, calves were delivered by Caesarean section. Calves were weaned when they weighed over $100 \mathrm{~kg}$ (about 3 months of age).

\section{Statistical analysis}

All values are presented as mean \pm S.E.M., unless indicated otherwise. Statistical significance was accepted at $P<0.05$ and determined using the onetailed Fisher exact test for independence in $2 \times 2$ tables for development data or the two-tailed $t$-test with equal variance for birth weight and gestation length data.

\section{Results}

\section{Timing of early fertilization events}

Disappearance of the MII plate was used to indicate oocyte activation at hourly intervals post-insemination (Fig. 2). No activation was observed at $2 \mathrm{hpi}, 4 \%$ at $3 \mathrm{hpi}$, $34 \%$ at $4 \mathrm{hpi}, 69 \%$ at $5 \mathrm{hpi}$, and $75 \%$ at $6 \mathrm{hpi}$. Activation rates further increased at $8(80 \%)$ and 10 hpi (89\%). There was no further significant increase between 13 (94\%) and 23 hpi (95\%). In all chemically activated oocytes, the MII plate had disappeared within $1 \mathrm{~h}$ postactivation (Fig. 2).

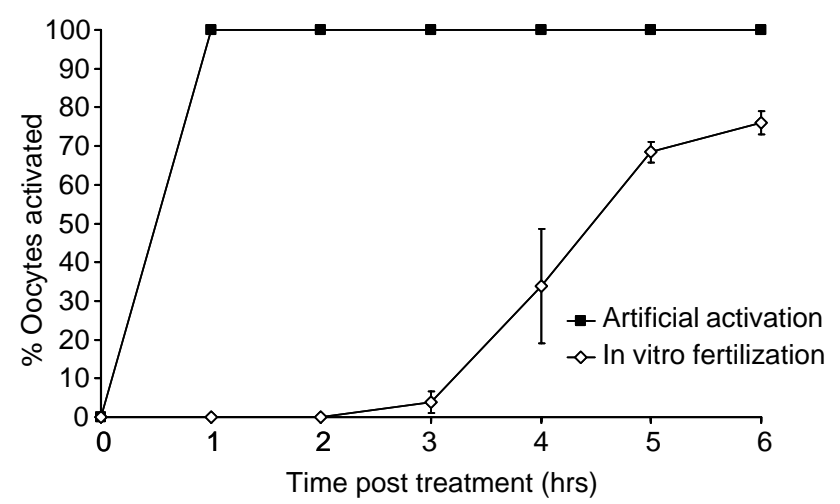

Figure 2 Time course of oocyte activation. At different time points after insemination, or artificial activation, the proportion of the total number of eggs that had either lost their MII plate or extruded a second polar body was quantified after fixation and staining with Hoechst 33342. For the IVF treatment group, values are presented as mean \pm S.E.M. ( $n=2$ or 3 independent experiments, $N=39-82$ eggs at each time point). For the artificially activated treatment group, $n=1$ experiment and $N=15$ eggs at each time point following artificial activation. 


\section{Effect of increased time between insemination and nuclear transfer}

As the time interval between insemination and NT increased from 4.5 to $7 \mathrm{hpi}$, development to blastocysts decreased from about 50 to below $10 \%$ respectively $(N=1062$ embryos, $n=25$ separate IVF times/dates, Fig. 3). The optimal time for achieving both relatively high fertilization and development rates was determined to be between 4 and 5 hpi (Figs 2 and 3). Figure 4A shows an example of a zygote at the same stage as those used at the time of enucleation (4-5 hpi).

\section{In vitro development of IVF-NT versus standard NT embryos}

An example of an IVF-NT embryo fixed $24 \mathrm{~h}$ post-fusion is shown in Fig. 4B. We first compared in vitro development of standard NT (artificially activated after fusion) and IVF-NT embryos (Table 1) and found that cleavage was higher (98 vs $95 \%$ respectively, $P=0.05$ ); but development into blastocysts $(B)$ grade $1-3\left(B^{1-3}\right)(39$ vs $40 \%$ respectively), or into $B$ grade $1-2\left(B^{1-2}\right)$ (20 vs $21 \%$ respectively) was not different. We also attempted to produce control NT embryos from artificially preactivated cytoplasts or MII oocytes. The time between the start of artificial activation and donor cell fusion ranged from 56 to $61 \mathrm{~min}$ for cytoplasts and from 55 to $193 \mathrm{~min}$ for oocytes. Despite their cleavage being similar to that of the parthenogenote controls, none of the preactivated NT controls developed to blastocysts (Table 2).

\section{In vivo development of IVF-NT versus standard NT embryos}

In order to correlate the results from in vitro development with in vivo developmental potential, we transferred

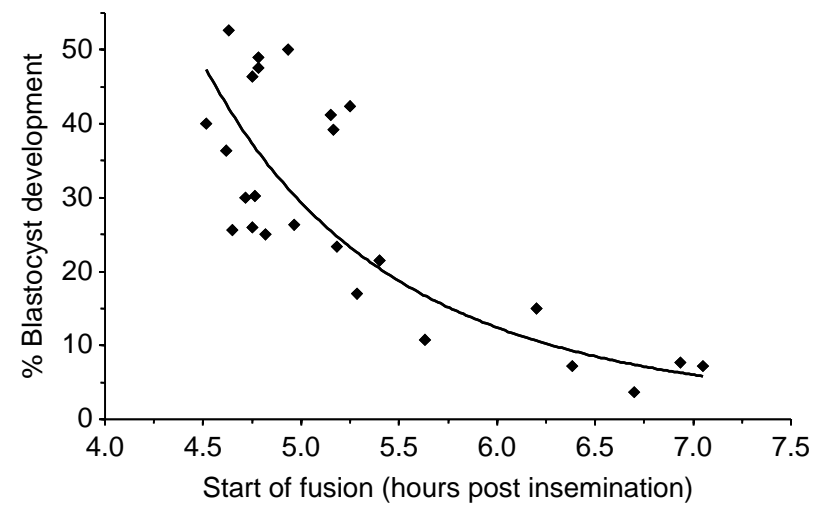

Figure 3 Development of IVF-NT embryos at different times between insemination and NT. Following different time intervals between insemination and electrical cell fusion, the proportion of the total number of reconstructed embryos placed into IVC that developed into blastocysts grade $1-3\left(\mathrm{~B}^{1-3}\right)$ was quantified after 7 days in vitro $(n=25$ independent NT experiments, $N=1062$ embryos). Power curve trend line of best fit has been included $\left(y=58166 x^{-4.7179}, R^{2}=0.7673\right)$.
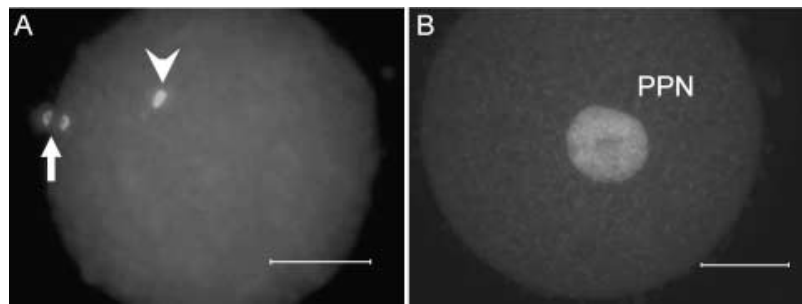

Figure 4 Morphology of IVF-NT embryos before enucleation and after NT. Embryos were fixed and stained with Hoechst 33342 immediately before enucleation (A) or $24 \mathrm{~h}$ after NT with serum-starved fibroblast donor cells (B). (A) The telophase Il-chromosomes (arrow) and condensed sperm DNA (arrowhead) are visible. (B) A single pseudopronucleus $(\mathrm{PPN})$ is shown. Scale bar $=50 \mu \mathrm{m}$.

grades 1 and 2 NT and IVF-NT embryos into recipient cows across four replicate runs (Fig. 5). Pregnancy establishment at D35 was significantly higher for sperm-activated than for chemically-activated NT embryos $(30 / 49=61$ vs $17 / 41=42 \%$ respectively, $P<0.05)$. Development into live calves at term or weaning was higher in the IVF-NT group compared with standard NT (Table 3), however, this difference was no longer statistically significant $(9 / 49=18$ vs $3 / 41=7 \%$ and $6 / 49=12$ vs $3 / 41=7 \%$ with $P=0.11$ and $P=0.34$ respectively). The incidence of hydroallantois was not different between IVF-NT versus standard NT fetuses $(6 / 49=12$ vs $6 / 41=15 \%$ respectively), but was completely absent in the artificially inseminated (AI) group. Of the nine IVF-NT calves born, three died before weaning. The first calf died at birth with a number of cloning-related pathologies (abnormalities in kidneys, thyroid and adrenals, and contracted tendons in all legs), the second died 3 days post-parturition as a result of fractured ribs (this death may have been prevented with caesarian birth), and the third died after 1 week post-parturition from rumenitis and pneumonia; this calf also had a contracted front tendon, a symptom of muscular-skeletal abnormalities common in our somatic bovine clones. Of the four standard NT calves born, one died at birth as a result of birthing difficulties from oversize; this death may have been avoided with a caesarian birth. The remaining six IVF-NT and three standard SCNT calves survived beyond weaning. All eight Al calves survived beyond weaning.

\section{Discussion}

We have evaluated the effect of sperm-mediated activation of bovine SCNT embryos on in vitro and in vivo development. We found that NT into early zygotic cytoplasts at TII resulted in similar in vitro development, but increased in vivo survival compared with NT into MII cytoplasts followed by chemical activation.

Cytoplasts prepared from non-activated MII and artificially activated TII oocytes are predominantly used for SCNT. Presently, there is no evidence that exposure of 
Table 1 In vitro development of cloned bovine embryos from NT and IVF-NT.

\begin{tabular}{|c|c|c|c|c|c|c|c|}
\hline Group & $N$ & Fusion $(\%)^{a}$ & nIVC & $\begin{array}{l}\text { Development (\%) } \\
\text { to } \geq \text { two-cell }^{\mathrm{b}}\end{array}$ & $\begin{array}{c}\text { Development (\%) } \\
\text { to } B^{1-3 b}\end{array}$ & $\begin{array}{c}\text { Development (\%) } \\
\text { to } B^{1-2 b}\end{array}$ & $\begin{array}{c}\text { Development (\%) } \\
\text { to } B^{1-2 C}\end{array}$ \\
\hline NT & 4 & $322 / 350(92.0)$ & 321 & $313(98)^{*}$ & $130(40)$ & $67(21)$ & 52 \\
\hline IVF-NT & 4 & $522 / 571$ (91.4) & 522 & $496(95)^{\dagger}$ & 202 (39) & $104(20)$ & 51 \\
\hline
\end{tabular}

$N$, Total number of independent NT experiments. ${ }^{+}{ }^{\dagger}$ Rows with different superscripts differ significantly $(P<0.05)$.

${ }^{\mathrm{a}}$ Proportion of total number of cytoplast-donor couplets manipulated that fused. ${ }^{\mathrm{b}}$ Proportion of total number of reconstructed embryos placed into IVC (nIVC) that either cleaved or developed into blastocysts $(B)$ grades $1-3\left(B^{1-3}\right)$ or into B grades $1-2\left(B^{1-2}\right)$. ${ }^{C}$ Proportion of $B^{1-2}$ of all $B^{1-3}$.

the donor chromatin to either MII or TII cytoplasm is inherently superior for epigenetic reprogramming. Nevertheless, it would have been more stringent to use cytoplasts of the same activation status for our study, for example, by directly comparing (i) artificially activated TII-cytoplasts versus sperm-activated early zygotes or (ii) non-activated MII cytoplasts that were artificially versus sperm-activated after NT. For various reasons, we were unable to carry out either of these comparisons. With regard to the first comparison (TII oocytes versus early zygotes), we did not obtain any blastocysts after NT of serum-starved donor cells into ionomycin/6-DMAPactivated cytoplasts (Table 2). This has been described before and is probably due to the rapid degradation of cyclin B, which destroys activity of cyclin B and Cdk 1 complexes (M-Cdk). Once M-Cdk-activity declines to basal levels, an introduced donor nucleus no longer undergoes nuclear envelope breakdown, presumably preventing efficient chromatin remodeling (Tani et al. 2001, 2003). We observed that within $30 \mathrm{~min}$ of ionomycin/6-DMAP treatment, all oocytes had lost their metaphase-plate compared with none in the fertilized group (Fig. 2 and data not shown). This is in agreement with a report on the disappearance of the MII plate and cyclin B and the decrease of M-Cdk-activity $1 \mathrm{~h}$ after activation with calcium ionophore A23187 and 6-DMAP (Liu \& Yang 1999). A similar decrease in M-Cdk-activity has also been described in ionomycin/ 6-DMAP-activated cytoplasts, where the most significant drop occurred within $1 \mathrm{~h}$ post-activation (Tani et al. 2003). In contrast to our data, this drop did not immediately interfere with development to blastocyst; however, NT was done with M-phase, not with $G_{0} / G_{1}$ phase donor cells. When the time between activation (by electric stimulation or ionomycin followed by $4-6 \mathrm{~h}$ incubation in 6-DMAP or cycloheximide respectively) and NT increased to $4-6 \mathrm{~h}$, development past the eightcell stage was almost completely abolished both with M-or $G_{0} / G_{1}$-phase donors (Tani et al. 2001, 2003). However, there are cases where artificially pre-activated TII cytoplasts have supported somatic chromatin remodeling after NT in cattle and mice (Bordignon et al. 1999, 2001), and even resulted in viable cloned goats (Baguisi et al. 1999) and cattle (Bordignon \& Smith 1998, Kurosaka et al. 2002, Bordignon et al. 2003). Some of these studies differ from ours in using different species, different activation stimuli (e.g., electrical current, ionomycin, and ethanol/cycloheximide) and activation times, and oocytes of different age post-maturation at the time of telophase enucleation. Not all those studies accurately quantified M-Cdk-activity, but it is reasonable to assume that it must have been still high enough to disassemble the donor nuclear envelope and allow embryo development to proceed.

The down-regulation of M-Cdk-activity appeared to have happened even more slowly in cytoplasts preactivated by IVF. First of all, sperm initially need to find the egg, bind to it, and penetrate the zona pellucida, then bind to and fuse with the egg plasma membrane before activation occurs. This delay of at least $2 \mathrm{~h}$ is evident from Fig. 2. Interestingly, even after sperm-egg fusion, the kinetics of artificial and sperm-mediated activation was different. The minimal time interval between chemical activation and NT was $56 \mathrm{~min}$ and development to blastocyst was nil (Table 2). In some IVF-NT groups, the interval between sperm-egg fusion and NT was longer than $56 \mathrm{~min}$, however, development to blastocyst was still $20 / 51=39 \%$, suggesting that at least some aspects of activation occur more rapidly in artificially activated eggs. This fits with previously reported morphological changes and quantitation of cyclin B abundance and M-Cdk-activity after IVF.

Table 2 In vitro development of cloned-bovine embryos from pre-activated cytoplasts or pre-activated oocytes.

\begin{tabular}{lccccc}
\hline Group & N & nIVC & $\begin{array}{c}\text { Development (\%) } \\
\text { to } \geq \text { two-cell }\end{array}$ & $\begin{array}{c}\text { Development (\%) } \\
\text { to B } \mathbf{B}^{\mathbf{1 - 3 a}}\end{array}$ & $\begin{array}{c}\text { Development (\%) } \\
\text { to B } \mathbf{B}^{\mathbf{1 - 2 a}}\end{array}$ \\
\hline Parthenogenote control & 1 & 59 & $46(78)$ & $36(61)$ & $20(34)$ \\
NT into activated cytoplast & 1 & 53 & $36(68)$ & 0 & 0 \\
NT into activated oocyte & 2 & 145 & $99(68)$ & 0 & 0
\end{tabular}

$N$, Total number of independent NT experiments; nIVC, total number of embryos cultured to day 7.

a Proportion of total number of reconstructed embryos placed into IVC (nIVC) that either cleaved or developed into blastocysts (B) grades $1-3$ (B ${ }^{1-3}$ ) or into $B$ grades $1-2\left(B^{1-2}\right)$. 


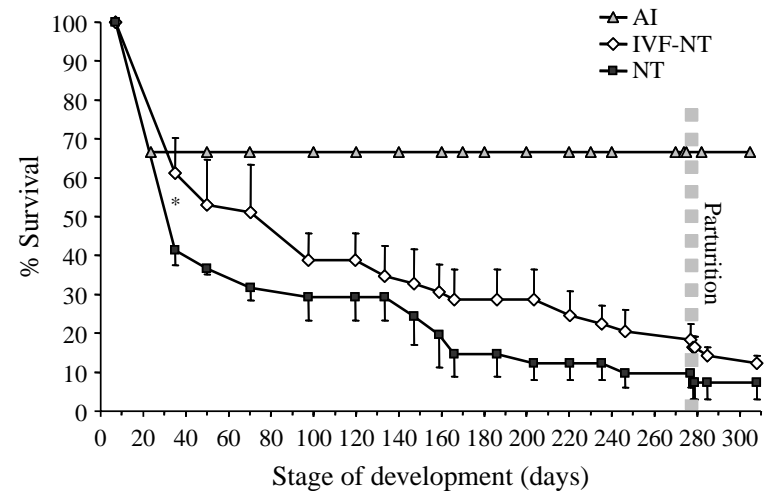

Figure 5 In vivo development of Al, NT, and IVF-NT bovine embryos. Clones were obtained after IVF-NT or control NT. Artificially inseminated cows served as additional controls (AI). Embryo survival was calculated as a proportion of total number of embryos transferred that developed into fetuses and calves ( $n=4$ independent experiments, $N=49$, and 41 for IVF-NT and NT respectively). Al embryo survival was calculated as a proportion of the total number of cows inseminated, since the number of cows pregnant with grades 1 and 2 blastocysts on D7 was not determined $(N=1, n=12)$. Values are mean \pm s.E.M., $* P<0.05$.

IVF-eggs had just commenced second polar body extrusion at $4 \mathrm{hpi}$, while cyclin B disappeared completely between 3 and $6 \mathrm{~h}$. A significant decrease in M-Cdk-activity started at $3 \mathrm{hpi}$ was most pronounced between 4 and $5 \mathrm{hpi}$ and started to plateau at basal levels after 5 h (Liu \& Yang 1999). All three events correlate with our data in Fig. 2. We have not measured M-Cdkactivity in IVF-NT cytoplasts $4-5 \mathrm{hpi}$, but there must have been still enough M-Cdk-activity to allow development into blastocysts. As with artificially activated TIIcytoplasts, the timing between activation and NT was very critical for sperm-activated eggs. Cloned blastocyst development was inversely proportional to the length of time between fertilization and NT (Fig. 3). At 4.5 hpi, total blastocyst development was just under $50 \%$, whereas at $7 \mathrm{hpi}$, it dropped to just above 5\% (Fig. 3). In mouse cloning, blastocyst development was nil after SCNT into zygotes that had already reached the pronuclei-stage, about 5-6 hpi (Wakayama et al. 2000).

With respect to the second possible comparison (MII cytoplasts that were artificially versus sperm-activated after NT), we in vitro fertilized non-activated SCNT reconstructs and tried to remove the sperm chromatin later. However, our attempts to identify and remove specifically the sperm but not the donor cell chromatin at various time points after NT were unsuccessful. We used different methods of marking and subsequently removing the sperm DNA without damaging the donor cell genome, however, they all proved to be impractical (Supplemental Fig. 1). Even in mouse, where the unstained male pronucleus can be more easily visualized in the zygote cytoplasm, its specific removal after NT was often unsuccessful (Kishikawa et al. 1999).

Apart from their different activation status, early zygotes differed from MII cytoplasts in several respects. First, sperm activation occurred around $25 \mathrm{~h}$ and artificial activation around $28 \mathrm{~h}$ post-IVM. In our experience with differently aged MII cytoplasts, a $3 \mathrm{~h}$ difference at the time of activation is unlikely to have a measurable impact on subsequent development. Second, different populations of oocytes were used for IVF-NT and standard NT. Oocytes that had extruded the first polar body were used for control NT, whereas only eggs that had extruded a second polar body 4 hpi were used for IVF-NT. By selecting eggs that had already advanced to the stage of second polar body extrusion, we might have slightly biased the in vitro development in favor of the IVF-NT group. Despite this, cleavage rate to two-cells was actually slightly, but significantly, lower in the IVF-NT versus control group (Table 1). Third, early zygotes are no longer developmentally arrested and may have been more compromised by the high degree of handling, e.g., the media and temperature changes that occurred during enucleation and NT. Fourth, enucleation of early zygotes was technically slightly more challenging. Aspiration of both sperm and maternal chromatin removed about twice the cytoplasmic volume as aspirating the maternal chromosomes alone, amounting to an average reduction in zygote volume of around $4 \%$ (Oback et al. 2003). Enucleation also took about twice as long as for MII oocytes (around 21 s), increasing the risk from u.v.-induced damage, either directly through DNA lesions (Tsunoda et al. 1988) in mitochondria, or effects on proteins or membrane integrity, or indirectly through activation of a DNA damage excisionrepair pathway in the zygote.

Some of these confounding factors may have masked potential benefits of using sperm-mediated activation to improve in vivo development of clones. Even though

Table 3 In vivo development of cloned-bovine embryos from AI, NT, and IVF-NT.

\begin{tabular}{|c|c|c|c|c|c|c|c|c|}
\hline Group & $N$ & $n$ & $\begin{array}{l}\text { Development } \\
\text { (\%) to day } 35^{\mathrm{a}}\end{array}$ & $\begin{array}{l}\text { Development } \\
(\%) \text { to term } \\
\text { b }\end{array}$ & $\begin{array}{l}\text { Development (\%) } \\
\text { to weaning }\end{array}$ & $\begin{array}{l}\text { Age at birth } \\
\text { (days } \pm \text { S.E.M.) }\end{array}$ & $\begin{array}{l}\text { Birth weight } \\
(\mathrm{kg} \pm \text { S.E.M. })\end{array}$ & Breed \\
\hline $\mathrm{Al}$ & 1 & 12 & $8(67)^{*}$ & $8(67)^{*}$ & $8(67)^{*}$ & $272 \pm 2^{b^{*}}$ & $39 \pm 3^{b^{*}}$ & Hereford $\times$ Friesian \\
\hline NT & 4 & 41 & $17(41)^{\dagger}$ & $4(10)^{\dagger}$ & $3(7)^{+}$ & $281 \pm 2^{\dagger}$ & $47 \pm 2^{+}$ & Friesian \\
\hline IVF-NT & 4 & 49 & $30(61)^{*}$ & $9(18)^{\dagger}$ & $6(12)^{+}$ & $277 \pm 1^{+}$ & $49 \pm 2^{y}$ & Friesian \\
\hline
\end{tabular}

$N$, Total number of independent NT or Al experiments; $n$, total number of embryo transferred (nET) or artificially inseminated (nAl). ${ }^{+}{ }^{+}$Rows with different superscripts differ significantly $(P<0.05)$.

${ }^{a}$ Proportion of total number of $\mathrm{nET}$ or $\mathrm{nAl}$ that developed into fetuses and live calves at day 35 of gestation, term or weaning. ${ }^{b}$ Only the four male calves were included in the weight and age analysis. 
pregnancy establishment was significantly higher for IVF-NT embryos, the fetal loss profile throughout development was similar in both treatment groups. For example, the incidence of hydroallantois that is typically associated with SCNT cloning did not differ between both treatments. Hydroallantois is a major animal welfare issue and we have chosen the AESF-1 cell line as it reproducibly results in higher frequency of hydropscases than all of our other cell lines tested (unpublished results). Any improvement on this particular phenotype should therefore have been easier to detect. Despite the occurrence of hydrops and other cloning-related phenotypes post-partum, there was still a clear trend for development into viable calves to be higher in the IVF-NT group due to the higher initial pregnancy rates.

There are several reasons why sperm-mediated activation may be advantageous over artificial activation and even injection of isolated sperm extracts (Knott et al. 2002, Hinrichs et al. 2006). First, sperm is the natural agent of activation. Mouse spermatozoa contain a sperm-specific member of the phospholipase C (PLC)

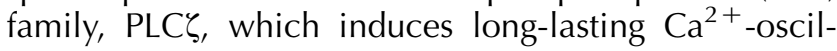
lations (Parrington et al. 2000, Saunders et al. 2002, Knott et al. 2005) that more closely resemble natural fertilization (Fissore et al. 1992, Deguchi et al. 2000) than the single, large $\mathrm{Ca}^{2+}$-rise triggered by artificial activation. Although a single $\mathrm{Ca}^{2+}$-rise is sufficient for the oocytes to undergo early activation events, such as cortical granule exocytosis and the resumption of meiotic division, repeated $\mathrm{Ca}^{2+}$-rises may be beneficial for later embryonic development (Ozil 1990). Second, the sperm delivers other factors to the egg that may be beneficial in supporting early embryonic development. These include: (i) the centrosome, an organelle which is particularly important during standard NT experiments since in bovine oocytes all microtubules are concentrated in the meiotic spindle (Schatten 1994) and are largely removed together with other centrosome-associated components during enucleation, (ii) some 3000 different kinds of mRNA (Ostermeier et al. 2002) at least some of which are specifically introduced into the egg after fertilization (Ostermeier et al. 2004), and (iii) microRNAs which do not code for proteins but play a role in controlling gene activity (Ostermeier et al. 2005). All these molecules may participate in chromatin remodeling, pronuclear formation, establishment of imprints, or embryonic genome activation (Krawetz 2005). They were likely to have entered the zygote cytoplasm to various degrees, depending on their subcellular localization in the sperm. For example, proteins in the perinuclear theca, i.e., the dense protein matrix between the sperm nucleus and plasma membrane, will take longer to release than those that with cytosolic or subplasma membrane localization. Third, there may be early sperm-derived transcripts that arise within the short time between sperm-egg fusion and enucleation. Even though there is no evidence for such early paternal transcriptional activity, it has become increasingly clear that there is some minor embryonic genome activation occurring shortly after fertilization in cattle (Memili et al. 1998). The nature of these early transcripts is not known and it is unclear whether they come from the maternal or paternal genome or both.

During aspiration of the sperm and maternal DNA, we would have to some extent removed these factors again, which may in part explain why sperm-mediated activation did not have a more obvious effect on overcoming cloning-related phenotypes and inefficiencies. In a previous report on somatic mouse cloning, insemination of NT reconstructs did not appear to be more efficient in supporting development into live fetuses than artificial activation with either strontium, ethanol, electric current, or intracytoplasmic sperm injection, however, this may have been due to technical problems of removing the sperm genome and low numbers of fetuses analyzed (Kishikawa et al. 1999). Our experimental results in cattle encourage further investigation in the general role of activation during NT cloning and specifically warrant a more detailed analysis into the benefits of sperm-mediated activation. This may ultimately provide a way of improving epigenetic reprogramming and cloning success.

\section{Acknowledgements}

We would like to thank our cloning team (A Green, P Misica, F Oback, and J Oliver) and past and present farm staff (J Forsyth, M Berg, and V Prendergast) for excellent technical assistance. This work was funded by the New Zealand Foundation for Research, Science and Technology and AgResearch. The authors declare that there is no conflict of interest that would prejudice the impartiality of this scientific work.

\section{References}

Baguisi A, Behboodi E, Melican DT, Pollock JS, Destrempes MM, Cammuso C, Williams JL, Nims SD, Porter CA, Midura P, et al. 1999 Production of goats by somatic cell nuclear transfer. Nature Biotechnology 17 456-461.

Boiani M, Eckardt S, Leu NA, Scholer HR \& McLaughlin KJ 2003 Pluripotency deficit in clones overcome by clone-clone aggregation: epigenetic complementation? EMBO Journal 22 5304-5312.

Bordignon V \& Smith LC 1998 Telophase enucleation: an improved method to prepare recipient cytoplasts for use in bovine nuclear transfer. Molecular Reproduction and Development 49 29-36.

Bordignon V, Clarke HJ \& Smith LC 1999 Developmentally regulated loss and reappearance of immunoreactive somatic histone $\mathrm{H} 1$ on chromatin of bovine morula-stage nuclei following transplantation into oocytes. Biology of Reproduction 61 22-30.

Bordignon V, Clarke HJ \& Smith LC 2001 Factors controlling the loss of immunoreactive somatic histone $\mathrm{H} 1$ from blastomere nuclei in oocyte cytoplasm: a potential marker of nuclear reprogramming. Developmental Biology 233 192-203.

Bordignon V, Keyston R, Lazaris A, Bilodeau AS, Pontes JH, Arnold D, Fecteau G, Keefer C \& Smith LC 2003 Transgene expression of green 
fluorescent protein and germ line transmission in cloned calves derived from in vitro-transfected somatic cells. Biology of Reproduction 68 2013-2023.

Bourc'his D, Le Bourhis D, Patin D, Niveleau A, Comizzoli P, Renard JP \& Viegas-Pequignot E 2001 Delayed and incomplete reprogramming of chromosome methylation patterns in bovine cloned embryos. Current Biology 11 1542-1546.

Brind S, Swann K \& Carroll J 2000 Inositol 1,4,5-trisphosphate receptors are downregulated in mouse oocytes in response to sperm or adenophostin A but not to increases in intracellular $\mathrm{Ca}(2+)$ or egg activation. Developmental Biology 223 251-265.

Campbell KH, McWhir J, Ritchie WA \& Wilmut I 1996 Sheep cloned by nuclear transfer from a cultured cell line. Nature $\mathbf{3 8 0}$ 64-66.

Chung YG, Mann MR, Bartolomei MS \& Latham KE 2002 Nuclearcytoplasmic 'tug of war' during cloning: effects of somatic cell nuclei on culture medium preferences of preimplantation cloned mouse embryos. Biology of Reproduction 66 1178-1184.

Colonna R, Tatone C, Malgaroli A, Eusebi F \& Mangia F 1989 Effects of protein kinase $\mathrm{C}$ stimulation and free $\mathrm{Ca}^{2+}$ rise in mammalian egg activation. Gamete Research 24 171-183.

Cuthbertson KS, Whittingham DG \& Cobbold PH 1981 Free $\mathrm{Ca}^{2+}$ increases in exponential phases during mouse oocyte activation. Nature 294 754-757.

Czolowska R, Modlinski JA \& Tarkowski AK 1984 Behaviour of thymocyte nuclei in non-activated and activated mouse oocytes. Journal of Cell Science 69 19-34.

Dean W, Santos F, Stojkovic M, Zakhartchenko V, Walter J, Wolf E \& Reik W 2001 Conservation of methylation reprogramming in mammalian development: aberrant reprogramming in cloned embryos. PNAS 98 13734-13738.

Deguchi R, Shirakawa H, Oda S, Mohri T \& Miyazaki S 2000 Spatiotemporal analysis of $\mathrm{Ca}(2+)$ waves in relation to the sperm entry site and animal-vegetal axis during $\mathrm{Ca}(2+)$ oscillations in fertilized mouse eggs. Developmental Biology 218 299-313.

Enright BP, Kubota C, Yang X \& Tian XC 2003 Epigenetic characteristics and development of embryos cloned from donor cells treated by trichostatin A or 5-aza-2'-deoxycytidine. Biology of Reproduction 69 896-901.

Fissore RA, Dobrinsky JR, Balise JJ, Duby RT \& Robl JM 1992 Patterns of intracellular $\mathrm{Ca}^{2+}$ concentrations in fertilized bovine eggs. Biology of Reproduction 47 960-969.

Galli C, Lagutina I, Vassiliev I, Duchi R \& Lazzari G 2002 Comparison of microinjection (piezo-electric) and cell fusion for nuclear transfer success with different cell types in cattle. Cloning and Stem Cells $\mathbf{4}$ 189-196.

Gaynor P, Wells DN \& Oback B 2005 Couplet alignment and improved electrofusion by dielectrophoresis for a zona-free high-throughput cloned embryo production system. Medical and Biological Engineering and Computing 43 150-154.

Graham CF 1974 The production of parthenogenetic mammalian embryos and their use in biological research. Biological Reviews of the Cambridge Philosophical Society 49 399-424.

Hinrichs K, Choi YH, Love CC, Chung YG \& Varner DD 2006 Production of horse foals via direct injection of roscovitine-treated donor cells and activation by injection of sperm extract. Reproduction 131 1063-1072.

Humpherys D, Eggan K, Akutsu H, Friedman A, Hochedlinger K, Yanagimachi R, Lander ES, Golub TR \& Jaenisch R 2002 Abnormal gene expression in cloned mice derived from embryonic stem cell and cumulus cell nuclei. PNAS 99 12889-12894.

Jellerette T, He CL, Wu H, Parys JB \& Fissore RA 2000 Downregulation of the inositol 1,4,5-trisphosphate receptor in mouse eggs following fertilization or parthenogenetic activation. Developmental Biology 223 238-250.

Kang YK, Koo DB, Park JS, Choi YH, Chung AS, Lee KK \& Han YM 2001 Aberrant methylation of donor genome in cloned bovine embryos. Nature Genetics 28 173-177.
Kang YK, Park JS, Koo DB, Choi YH, Kim SU, Lee KK \& Han YM 2002 Limited demethylation leaves mosaic-type methylation states in cloned bovine pre-implantation embryos. EMBO Journal 21 1092-1100.

Kato Y, Tani T, Sotomaru Y, Kurokawa K, Kato J, Doguchi H, Yasue H \& Tsunoda Y 1998 Eight calves cloned from somatic cells of a single adult. Science 282 2095-2098.

Kaufman MH 1983 Early Mammalian Development: Parthenogenetic Studies, London: Cambridge University Press.

Kishikawa H, Wakayama T \& Yanagimachi R 1999 Comparison of oocyte-activating agents for mouse cloning. Cloning 1 153-159.

Kishigami S, Mizutani E, Ohta H, Hikichi T, Thuan NV, Wakayama S, Bui HT \& Wakayama T 2006 Significant improvement of mouse cloning technique by treatment with trichostatin A after somatic nuclear transfer. Biochemical and Biophysical Research Communications 340 183-189.

Knott JG, Poothapillai K, Wu H, He CL, Fissore RA \& Robl JM 2002 Porcine sperm factor supports activation and development of bovine nuclear transfer embryos. Biology of Reproduction 66 1095-1103.

Knott JG, Kurokawa M, Fissore RA, Schultz RM \& Williams CJ 2005 Transgenic RNA interference reveals role for mouse sperm phospholipase Czeta in triggering $\mathrm{Ca}^{2+}$ oscillations during fertilization. Biology of Reproduction 72 992-996.

Koo DB, Kang YK, Choi YH, Park JS, Kim HN, Oh KB, Son DS, Park H, Lee KK \& Han YM 2002 Aberrant allocations of inner cell mass and trophectoderm cells in bovine nuclear transfer blastocysts. Biology of Reproduction 67 487-492.

Krawetz SA 2005 Paternal contribution: new insights and future challenges. Nature Reviews Genetics 6 633-642.

Kurosaka S, Nagao Y, Minami N, Yamada M \& Imai H 2002 Dependence of DNA synthesis and in vitro development of bovine nuclear transfer embryos on the stage of the cell cycle of donor cells and recipient cytoplasts. Biology of Reproduction 67 643-647.

Liu L \& Yang X 1999 Interplay of maturation-promoting factor and mitogen-activated protein kinase inactivation during metaphaseto-interphase transition of activated bovine oocytes. Biology of Reproduction 61 1-7.

Mann MR, Chung YG, Nolen LD, Verona RI, Latham KE \& Bartolomei MS 2003 Disruption of imprinted gene methylation and expression in cloned preimplantation stage mouse embryos. Biology of Reproduction 69 902-914.

Memili E, Dominko T \& First NL 1998 Onset of transcription in bovine oocytes and preimplantation embryos. Molecular Reproduction and Development 51 36-41.

Miyazaki S, Hashimoto N, Yoshimoto Y, Kishimoto T, Igusa Y \& Hiramoto Y 1986 Temporal and spatial dynamics of the periodic increase in intracellular free calcium at fertilization of golden hamster eggs. Developmental Biology 118 259-267.

Oback B \& Wells DN 2003 Cloning cattle. Cloning Stem Cells 5 $243-256$

Oback B, Wiersema AT, Gaynor P, Laible G, Tucker FC, Oliver JE, Miller AL, Troskie HE, Wilson KL, Forsyth JT, et al. 2003 Cloned cattle derived from a novel zona-free embryo reconstruction system. Cloning Stem Cells 5 3-12.

Ono Y, Shimozawa N, Ito M \& Kono T 2001 a Cloned mice from fetal fibroblast cells arrested at metaphase by a serial nuclear transfer. Biology of Reproduction 64 44-50.

Ono Y, Shimozawa N, Muguruma K, Kimoto S, Hioki K, Tachibana M, Shinkai Y, Ito M \& Kono T 2001 b Production of cloned mice from embryonic stem cells arrested at metaphase. Reproduction 122 731-736.

Ostermeier GC, Dix DJ, Miller D, Khatri P \& Krawetz SA 2002 Spermatozoal RNA profiles of normal fertile men. Lancet $\mathbf{3 6 0}$ 772-777.

Ostermeier GC, Miller D, Huntriss JD, Diamond MP \& Krawetz SA 2004 Reproductive biology: delivering spermatozoan RNA to the oocyte. Nature 429154. 
Ostermeier GC, Goodrich RJ, Moldenhauer JS, Diamond MP \& Krawetz SA 2005 A suite of novel human spermatozoal RNAs. Journal of Andrology 26 70-74.

Ozil JP 1990 The parthenogenetic development of rabbit oocytes after repetitive pulsatile electrical stimulation. Development 109 117-127.

Park ES, Hwang WS, Jang G, Cho JK, Kang SK, Lee BC, Han JY \& Lim JM 2004 Incidence of apoptosis in clone embryos and improved development by the treatment of donor somatic cells with putative apoptosis inhibitors. Molecular Reproduction and Development 68 65-71.

Parrington J, Lai FA \& Swann K 2000 The soluble mammalian sperm factor protein that triggers $\mathrm{Ca}^{2+}$ oscillations in eggs: evidence for expression of mRNA(s) coding for sperm factor protein(s) in spermatogenic cells. Biology of the Cell 92 267-275.

Robertson I \& Nelson R 1998 Certification and identification of the embryo. In Manual of the International Embryo Transfer Society, edn 3 edn, Eds DA Stringfellow \& SM Seidel. Illinois: International Embryo Transfer Society.

Santos F, Zakhartchenko V, Stojkovic M, Peters A, Jenuwein T, Wolf E, Reik W \& Dean W 2003 Epigenetic marking correlates with developmental potential in cloned bovine preimplantation embryos. Current Biology 13 1116-1121.

Saunders CM, Larman MG, Parrington J, Cox LJ, Royse J, Blayney LM, Swann K \& Lai FA 2002 PLC zeta: a sperm-specific trigger of $\mathrm{Ca}(2+)$ oscillations in eggs and embryo development. Development 129 3533-3544.

Schatten G 1994 The centrosome and its mode of inheritance: the reduction of the centrosome during gametogenesis and its restoration during fertilization. Developmental Biology 165 299-335.

Shimozawa N, Ono Y, Kimoto S, Hioki K, Araki Y, Shinkai Y, Kono T \& Ito $\mathbf{M} 2002$ Abnormalities in cloned mice are not transmitted to the progeny. Genesis 34 203-207.

Suemizu H, Aiba K, Yoshikawa T, Sharov AA, Shimozawa N, Tamaoki N \& Ko MS 2003 Expression profiling of placentomegaly associated with nuclear transplantation of mouse ES cells. Developmental Biology 253 36-53.

Sullivan EJ, Kasinathan S, Kasinathan P, Robl JM \& Collas P 2004 Cloned calves from chromatin remodeled in vitro. Biology of Reproduction 70 146-153.

Sun FZ, Hoyland J, Huang X, Mason W \& Moor RM 1992 A comparison of intracellular changes in porcine eggs after fertilization and electroactivation. Development 115 947-956.

Susko-Parrish JL, Leibfried-Rutledge ML, Northey DL, Schutzkus V \& First NL 1994 Inhibition of protein kinases after an induced calcium transient causes transition of bovine oocytes to embryonic cycles without meiotic completion. Developmental Biology 166 729-739.

Swann K \& Ozil JP 1994 Dynamics of the calcium signal that triggers mammalian egg activation. International Review of Cytology $\mathbf{1 5 2}$ 183-222.

Szollosi D, Czolowska R, Soltynska MS \& Tarkowski AK 1986 Remodelling of thymocyte nuclei in activated mouse oocytes: an ultrastructural study. European Journal of Cell Biology 42 140-151.
Szollosi D, Czolowska R, Szollosi MS \& Tarkowski AK 1988 Remodeling of mouse thymocyte nuclei depends on the time of their transfer into activated, homologous oocytes. Journal of Cell Science 91 603-613.

Tani T, Kato Y \& Tsunoda Y 2001 Direct exposure of chromosomes to nonactivated ovum cytoplasm is effective for bovine somatic cell nucleus reprogramming. Biology of Reproduction 64 324-330.

Tani T, Kato Y \& Tsunoda Y 2003 Reprogramming of bovine somatic cell nuclei is not directly regulated by maturation promoting factor or mitogen-activated protein kinase activity. Biology of Reproduction 69 1890-1894.

Tarkowski AK 1975 Induced parthenogenesis in the mouse. Symposium of the Society Developmental Biology 33 107-129.

Thompson JG, McNaughton C, Gasparrini B, McGowan LT \& Tervit HR 2000 Effect of inhibitors and uncouplers of oxidative phosphorylation during compaction and blastulation of bovine embryos cultured in vitro. Journal of Reproduction Fertility 118 47-55.

Tsunoda Y, Shioda Y, Onodera M, Nakamura K \& Uchida T 1988 Differential sensitivity of mouse pronuclei and zygote cytoplasm to Hoechst staining and ultraviolet irradiation. Journal of Reproduction Fertility 82 173-178.

Wakayama T, Perry AC, Zuccotti M, Johnson KR \& Yanagimachi R 1998 Full-term development of mice from enucleated oocytes injected with cumulus cell nuclei. Nature 394 369-374.

Wakayama T, Tateno H, Mombaerts P \& Yanagimachi R 2000 Nuclear transfer into mouse zygotes. Nature Genetics 24 108-109.

Wells DN 2003 Cloning in livestock agriculture. Reproduction 61 131-150.

Wells DN, Laible G, Tucker FC, Miller AL, Oliver JE, Xiang T, Forsyth JT, Berg MC, Cockrem K, L'Huillier PJ, et al. 2003 Coordination between donor cell type and cell cycle stage improves nuclear cloning efficiency in cattle. Theriogenology 59 45-59.

Wells DN, Forsyth JT, McMillan V \& Oback B 2004 The health of somatic cell cloned cattle and their offspring. Cloning Stem Cells $\mathbf{6}$ 101-110.

Wilmut I, Schnieke AE, McWhir J, Kind AJ \& Campbell KH 1997 Viable offspring derived from fetal and adult mammalian cells. Nature 385 810-813.

Wittingham DG 1980 Parthenogenesis in mammals. In Oxford Reviews of Reproductive Biology, Ed. CA Finn. Oxford: Clarender Press.

Yanagimachi R 1994 Mammalian fertilization. In Physiology of Reproduction, pp 189-317. Eds E Knobil \& JD Neil. New York: Raven Press.

Received 5 June 2006

First decision 14 July 2006

Revised manuscript received 21 August 2006

Accepted 29 August 2006 